\title{
On Interpretations of the Logical Relationship between the Chinese Dream and Socialist Core Values
}

\author{
Jing Liang ${ }^{1, a^{*}}$ \\ ${ }^{1}$ The Engineering and Technical College of Chengdu University of Technology, Leshan, China \\ a1035090705@qq.com
}

Keywords: The chinese dream; Socialist core values; Guidance; Bearing

\begin{abstract}
Ideals, goals and values of the Chinese dream are consistent with the value norms, moral standards and beliefs of socialist core values in the state, society and individuals. The realization of the Chinese dream is the materialization of socialist core values by constant practice and exploration, while socialist core values guide and support the Chinese dream to come true by providing the theoretical foundation and ideological support for the interpretation of values of the Chinese dream and ways to realize it.
\end{abstract}

\section{Introduction}

Chairman Xi first interpreted the concept of the Chinese dream in November, 2012, which is consistent with the value orientation of socialist core values in the state, people and individuals, for both the two bear the dreams of the whole nation to realize national rejuvenation, national prosperity and people's happiness. Socialist core values, as a social ideology, make clear the value norms, moral standards and beliefs in the growth and development of the whole society, and link the Chinese dream and Chinese spirit [1]. In the constant practice and exploration, the Chinese dream practices and materializes socialist core values, while the latter gives the guidance and support for the former to come true by providing the theoretical foundation and ideological support for the interpretation of values of the Chinese dream and ways to realize it.

\section{The Chinese Dream}

According to Chairman $\mathrm{Xi}$ in the 12th National People's Congress, the Chinese dream is a dream to realize the great rejuvenation of the nation, the final blueprint of national prosperity, national revival and people's happiness. The key to realize this dream is that we must rely firmly on the people. National prosperity and national revival are the goal and ideal that the whole nation has been struggling for, and also the premise of achieving personal goals in life and gaining and guaranteeing happiness for individuals. The Chinese dream, with the most extensive national consensus, the strongest national feelings and the thorough national beliefs, is of the state, of the people and of the individual,. It is deeply rooted and branded in the whole people, for it originated in the period when China suffered a lot. The revival of the whole nation is the dream that all Chinese people believe in, persist in and stick to. To realize the dream is to prosper the nation by promoting the coordinated development of economy and spiritual civilization, to stand out in the world and to provide an equally free platform for people to develop and realize their personal values.

\section{Socialist Core Values}

Value is the cognition, understanding, judgment or decision based on people's senses and thoughts [2], having features of stability, durability, historically, selectivity and subjectivity. Core values are the standards and norms of a group of people occupying dominant position when they govern and make decisions for the social affairs. Socialist core values advocate prosperity, democracy, civilization and harmony, advocate freedom, equality, justice and law and order, and advocate patriotism, professional integrity, credibility and friendliness, which give a clear definition to the goal, orientation and criterion 
for the state, society and people in the process of constructing a socialist country with distinct Chinese characteristics. The values are the vivid expression of the common value Chinese people seek and the greatest common divisor Chinese people struggle for[3]. They reflect the dream of national revival of Chinese people and the value norms in the process of harmonious development of the society and economy, and agree with the basic norms and demands to people's behaviors and morals. To practice the three advocates is for the realization of the Chinese dream.

\section{The Chinese Dream Bears and Practices Socialist Core Values}

To realize national prosperity, national revival and people's happiness is what the Chinese dream is really about. Only when the nation prospers could make people confident to stand out in the nations of the world. And people's happiness is guaranteed by national prosperity and national revival. No country, no home. Without a strong sense of belonging to his motherland, how can a person find his place in the competitive world? Stable economy provides a solid material security for people, national revival leaves a remarkable mental outlook for people's happiness and individuals devote to the country and the nation, push and quicken the process of prosperity and revival. The three advocates of socialist core values is for people's happiness and interests from the three aspects of our nation, society and individuals. The socialist core value system agrees with the basic situation and the trend of development of China. Socialist core values, as the most important part of the system, highly concise the value norms and moral standards, and display the connotation and rules of development of Chinese-style socialism. And the Chinese dream bears the consensus of Chinese people and their strong spiritual pursuits and value ideals, reflects the value norms, moral standards and beliefs of socialist core values in the state, society and individuals, and constantly practices the core values in the process of its realization.

National prosperity is the requirement of the Chinese dream to the state, and the main part of socialist core values. Materials determine consciousness, and consciousness reflects materials. National prosperity not only provides a solid material foundation for socialist core values, but also practices, perfect and refines the values in the process of its realization to better fit in with the basic conditions of China and the nature of Chinese-style socialism. To realize the Chinese dream must go the way with Chinese characteristics, for it is the goal of Chinese people to struggle for after they went through difficult times and summarize their experience in economy after liberation and rich Chinese civilization, and the pole for socialist core values to be in the right direction in the process of perfection and refining. The realization of national prosperity is the dream of all Chinese people, which motivate them greatly.

National revival is the value goal of the Chinese dream to the people, the goal of Chinese people struggle for, and the inevitable demand of socialist core values to establish value order and develop harmoniously and sustainably. Chairman Xi points that to realize the Chinese dream is to highlight the Chinese spirit, for it is formed by the people in the national integration, regards patriotism as the core and adopts the essence of Chinese civilization. By highlighting the Chinese sprit, all nationalities of China would be together to overcome all the difficulties and move forward to the same goal. In Chinese history, China is a country where nationalities experienced conflicts and then gradually integrate into a big family. The reform and open-up policy and the development of socialist market economy bring vitality to the whole society, but they also bring all kinds of thoughts and values to the levels of society. In such kind of situation, how China, this multinational country, reacts in the fog of thoughts and rush of values determines whether China can persist in the Chinese-style socialism. Freedom, equality, justice and law and order are the foundations for a country to develop healthily and stably and the demand of every citizen. To establish such kind of social environment is to give a fair society for every citizen to enjoy the rights and obligations freely and equally, and to establish a harmonious, fair and stable environment for the construction of Chinese-style socialism. Socialist core values can call for all nationalities to untie and contribute their power to the national revival, which would make all members further read the core values and clear their misunderstandings of and resistance to the core values, and therefore struggle for the same values. As an ideology, socialist core values needs to be perfected and refined in constant practice and exploration, which the Chinese dream can do. 
People's happiness is the respect and guarantee of the Chinese dream to individuals' values and dreams, and the final value goal of socialist core values. The Chinese dream must rely firmly on the people, which actually show that the Chinese dream is a dream for people's happiness. National prosperity and national revival is for people to live happily, which is the only purpose of an honest and upright political system and prosperous economy and culture. In other words. The final value goal of socialist core values is for people's happiness, and so the recognition of people to socialist core values is the breakthrough to culture and values. Patriotism, professional integrity, credibility and friendliness are the value norms of socialist core values to individuals. Patriotism can call all the powers of people; professional integrity and credibility is the moral standards for individuals in their professions and communications with others; and friendliness considers the differences among people in society and gives care and warmth to establish a society of tolerance, forgiveness and tremendous absorptive captivity .

The Chinese dream and socialist core values both aim at how to realize the best interests and all-around development of people. To strengthen people's recognition to socialist core values is an effective way to arouse their recognition and passion to the Chinese dream [4]. The realization of the Chinese dream must rely on the powers of all nationalities, for which could provide a good humanistic environment and a healthy and stable society to motivate people to realize their dreams and values. Under the leadership of Chinese Communist Party, people have been liberated, achieved economic take-offs and obtained freedom and live in a free and fair environment. They are the power of China, the backbone of China's strength. The Chinese dream is the value pursuit and value orientation of Chinese people. It is for the people. It is admitted that only the Chinese dream can hold people together to practice socialist core values and devote their life to national revival.

\section{Socialist Core Values Guide and Support the Chinese Dream to Come True}

The main body of the three advocates of socialist core values is people, which reflect that we stick to the general position that we must firmly rely on people. With the guidance and support of socialist core values, the whole nation could overcome all barriers and clear the fog of thoughts to respect and tolerate differences to reach a common consensus and realize the Chinese dream.

Prosperity, democracy, civilization and harmony are the requirements of the Chinese dream to the nation, reflecting the nature of socialism. Comrade Deng Xiaoping has already claimed that the essence of socialism is to liberate and develop productive forces to achieve common prosperity ultimately. Prosperity is the basic value pursuit and drive for a nation in materials. In the process of prosperity, Chinese people choose to go the way to the Chinese-style socialism. Only by this can realize the Chinese dream which is for the nation revival. The very nature of democracy is that people are masters. Prosperity can bring about abundant materials, while civilization and harmony a rich spiritual life.

Freedom, equality, justice and law and order are the value orientation of socialist collectivism for the Chinese dream. Freedom and equality are the important standards for the Chinese dream to realize its social goals, and justice and law and order are the precondition and essential conditions for the Chinese dream [5]. Under the socialist rule of law, a person should have the freedom of his own power, existence and development, and should take responsibility of his own behaviors. All men are equal before the law. By justice, the freedom and equality of a citizen will be realized, and in turn, freedom and equality are the essential precondition for justice. And all the three must be secured under the rule of law. Only when people live in a society of freedom, equality, justice and law and order can they have a stable society with sound development to develop all around and devote enthusiastically to the dream of national revival.

Patriotism, professional integrity, credibility and friendliness are the moral standards for Chinese people and define the direction of individuals' development. Patriotism is the core of national spirit, the basic element of socialist core value system and the invincible spiritual power for the Chinese dream to realize. Professional integrity is the essential for a person to realize his own dream and values, and the basic moral standard for his profession. Credibility is the most important moral requirement for a person to establish trust and good relationships with others. It demands that a person should treat others honestly; otherwise, he would damage his own career or image. Meanwhile, friendliness requires people 
to be kind to and care others to establish and maintain good and harmonious relationships with others. Credibility and friendliness could help people trust each other and humanize their relationships.

\section{References}

[1] Li Zhongjun. Zhongguomeng.Shehuizhuyi Jiazhiguan·Zhongguo Jingshen Sanweiyiti de Zhuhun Luoji [J]. Social Science Front, 2015(6): 9-15.

[2] Yuan Guiren. Jiazhiguan de Lilun yu Shijian[M]. Beijing: Beijing Normal University Publishing Group, 2013.

[3] Liu Yunshan. Zhuoli Peiyu he Jianxig Shehuizhuyi Hexin Jiazhiguan. Retrieved from www. cpcnews. cn on Feb., 15th, 2016.

[4] Wang Yingjie. Fangxiang yu Liliang_Jiedu Shehuizhuyi Jiazhiguan dui Zhongguomeng de Shuangchong Yiyi [J]. Journal of Inner Mongolia Agricultural University (Social Science Edition), 2013(6):1-4.

[5] Dong Junming \& Zhang Aiping. Yi Shehuizhuyi Hexin Jiazhiguan Zhutui Shixian "Zhongguomeng" [J]. Journal of Inner Mongolia Normal University (Educational Science), 2014(7):47-49. 